\title{
Developmental, Genetic, and Environmental Components of Aerobic Capacity at High Altitude
}

\author{
A. ROBERTO FRISANCHO, HEDY G. FRISANCHO, \\ MARK MILOTICH, TOM BRUTSAERT, RACHEL ALBALAK, \\ HILDE SPIELVOGEL, MERCEDEZ VILLENA, \\ ENRIQUE VARGAS, AND RUDY SORIA \\ Center for Growth and Development, University of Michigan, Ann Arbor, \\ Michigan 48109 (A.R.F., H.G.F., M.M., R.A.); Division of Nutritional \\ Sciences, Cornell University, Ithaca, New York 14853 (T.B.); Instituto \\ Boliviano de Biologia de Altura, Casilla 641, La Paz, Bolivia (H.S., M.V. \\ E.V., R.S.)
}

KEY WORDS Aerobic capacity, High altitude, Hypoxia, Adaptation, Bolivian Natives, Europeans

\begin{abstract}
The aerobic capacity of 268 subjects (158 males and 110 females) was evaluated in La Paz, Bolivia situated at $3,750 \mathrm{~m}$. The sample included 1) 39 high altitude rural natives (all male); 2) 67 high altitude urban natives (32 male, 35 female); 3 ) 69 Bolivians of foreign ancestry acclimatized to high altitude since birth (37 male, 32 female); 4) 50 Bolivians of foreign ancestry acclimatized to high altitude during growth ( 25 male, 25 female); and 5) 43 non-Bolivians of either European or North American ancestry acclimatized to high altitude during adulthood ( 25 male, 18 female). Data analyses indicate that 1) high altitude urban natives, acclimatized to high altitude since birth or during growth, attained higher aerobic capacity than subjects acclimatized to high altitude during adulthood;2) age at arrival to high altitude is inversely related to maximum oxygen consumption ( $\dot{\mathrm{V}}_{2} \max$ ) expressed in terms $\mathrm{L} / \mathrm{min}$ or $\mathrm{ml} / \mathrm{min} / \mathrm{kg}$ of lean body mass, but not in terms of $\mathrm{ml} / \mathrm{min} / \mathrm{kg}$ of body weight; 3 ) among subjects acclimatized to high altitude during growth, approximately $25 \%$ of the variability in aerobic capacity can be explained by developmental factors; 4) as inferred from evaluations of skin color reflectance and sibling similarities, approximately 20 to $25 \%$ of the variability in aerobic capacity at high altitude can be explained by genetic factors; 5) except among the non-Bolivians acclimatized to high altitude during adulthood, the aerobic capacity of individuals with high occupational activity level is equal to the aerobic capacity of high altitude rural natives; and 6) the relationship between occupational activity level and aerobic capacity is much greater among subjects acclimatized to high altitude before the age of 10 years than afterwards. Together these data suggest that the attainment of normal aerobic capacity at high altitude is related to both developmental acclimatization and genetic factors but its expression is highly mediated by environmental factors, such as occupational activity level and body composition. (1995 Wiley-Liss, Inc.
\end{abstract}

In general, work capacity (or aerobic capacity) is defined as the maximum oxygen intake per unit of body weight during maximal work. As such, it measures the capacity of the working muscles to use oxygen, and the ability of the cardiovascular system to transport and deliver oxygen to the tissues. Sea level natives sojourning at high altitude

\footnotetext{
Received July 11, 1994; accepted November 18, 1994.

Address reprint requests to Dr. A. Roberto Frisancho, Center for Human Growth and Development, $300 \mathrm{~N}$. Ingalls, University
} of Michigan, Ann Arbor, MI 48109-0406. 
exhibit a marked reduction in maximal aerobic capacity $\left(\mathrm{V}_{2} \mathrm{max}\right)$, while high altitude natives generally have $\dot{\mathrm{VO}}_{2}$ max levels equivalent to those of sea level individuals (Baker, 1976; Buskirk, 1976; Elsner et al., 1964; Frisancho et al., 1973; Grover et al., 1967; Kollias et al., 1968; Lahiri et al., 1967; Mazess, 1969; Velásquez, 1966, 1970; Velásquez and Reynafarje, 1966; Way, 1976). An enduring question is the extent to which this characteristic reflects differences in acclimatization based on genetic differences, or simply reflects population differences in adaptation based on environmental factors. In other words, the extent to which this characteristic is acquired or genetic is not well defined. In a previous study we advanced the hypothesis that the relatively high $\mathrm{VO}_{2}$ max of the high altitude native is the result of a developmental adaptation to high altitude hypoxia (Frisancho, 1975). This hypothesis was based on the finding that Peruvian sea level subjects raised at high altitude since childhood attained $\mathrm{VO}_{2}$ max similar to high altitude natives, but $\mathrm{Pe}-$ ruvian and US sea level adult natives who resided at high altitude for as long as 2 years attained lower $\dot{\mathrm{VO}}_{2}$ max levels than high altitude natives. Due to the fact that there has been a great deal of admixture among Peruvian populations, it is possible that the similarity between sea-level Peruvians raised (during childhood) at high altitude and high altitude natives may be due to their genetic similarities rather than reflecting a developmental factor. For this reason we studied the bioenergetics during maximal exercise of foreigners (Europeans and North Americans) acclimatized to high altitude during adulthood, Bolivians of foreign ancestry acclimatized to high altitude either since birth or during growth, and high altitude natives living in the rural and urban areas of $\mathrm{La}$ Paz, Bolivia.

\section{MATERIALS AND METHODS Subjects}

The sample consisted of 268 subjects ( 158 male, 110 female) studied in the city of La Paz, Bolivia, situated at $3,712 \mathrm{~m}$ above sealevel. The age of the subjects ranged from 13 to 49 years and included the following.
1. 39 high altitude rural natives (HARN) residing in the village of Taucachi situated at 4,100 m outside of La Paz.

2. 67 high altitude urban naties (HAUN) (32 male, 35 female).

3. 69 Bolivians of foreign ancestry acclimatized to high altitude since birth (AHAB) ( 37 male, 32 female).

4. 50 Bolivians of foreign ancestry acclimatized to high altitude during growth (AHAG) (25 male, 25 female).

5. 43 non-Bolivians of either European or North American ancestry acclimatized to high altitude during adulthood (AHAA) (25 male, 18 female).

\section{Measurements of body size and composition}

The subjects were evaluated through standard anthropometric techniques that included measurements of stature, weight, and skinfold thickness at the triceps, sub scapula, supra iliac, and median calf. Body mass index (wt/height squared) and sum of skinfold thicknesses (sum of triceps, subscapular, supra iliac, and calf skinfolds) were obtained by computation.

\section{Estimates of body composition}

Measurements of whole body resistance were obtained with a bioelectrical impedance analyzer (model 1990B; Valhalla, Scientific, San Diego, CA). Subjects assumed a supine position with arms and feet spread and shoes and socks were removed. The detecting electrodes were placed on the dorsal aspect of the right wrist midway between the radial and lunar processes, and the anterior aspect of the right ankle midway between the tibia and fibia's malleoli. Total body resistance $(R)$ was recorded to the nearest $\mathrm{ohm}(\Omega)$. The equation of Kushner et al. (1992) was used to estimate total body water. Based on this information the following values were calculated.

1. Lean body mass, $\mathrm{kg}(\mathrm{LBM})=$ Total body water/0.732.

2. Fat weight $=$ Total body weight $(\mathrm{kg})$ - LBM (kg).

3. \% Fat weight $(\%)=($ Fat weight $(\mathrm{kg}) /$ total body weight $(\mathrm{kg})) * 100$. 


\section{Skin color reflectance}

Measurements of skin reflectance were made with a Photovolt Reflectometer, model 575. Reflectance readings were made following the same procedures used in our previous study (Frisancho et al., 1981). This included measurements with two filters identified as triamber and trigreen. These filters have transmission peaks of approximately $600 \mathrm{~nm}$ (triamber) and $550 \mathrm{~nm}$ (trigreen) (Conway and Baker, 1972; Frisancho et al., 1981). At least two readings at the inner arm distal to the axillary region were obtained on each participant. Reflectance readings given by both filters were averaged for each subject and these were used in the present analysis.

\section{Exercise test}

The exercise tests were conducted in the bioenergetics laboratory of the Instituto Boliviano de Biologia de Altura (IBBA) in La $\mathrm{Paz}(3,750 \mathrm{~m})$. The environmental parameters (mean $\pm \mathrm{SD}$ ) were $500 \pm 0.9 \mathrm{mmHg}$ for barometric pressure and $16.5 \pm 1.5^{\circ} \mathrm{C}$ for ambient room temperature. Exercise tests were conducted on a Monark cycle ergometer. Pedaling frequency was maintained at $70 \mathrm{rpm}$. Heart rate (HR) and arterial oxygen $\left(\mathrm{SAO}_{2}\right)$ were monitored continuously using a Polar heart rate monitor (Polar Vantage XL) and an ear oximeter (Ohmeda 310) throughout the test. Samples of expired air were collected in Douglas bags and measured for volume with a Tissot spirometer. Temperature and pressure were used to correct gas volumes BTPS (body temperature, ambient pressure) and STPD (standard temperature and pressure, dry). The fractions of $\mathrm{O}_{2}$ and $\mathrm{CO}_{2}$ in the expired air were determined with a Servomex 570A and a Capnograph Gould Mark III. Pulmonary ventilation (VE), respiratory exchange ratio $\left(\mathrm{RQ}=\dot{\mathrm{V}} \mathrm{CO}_{2} \mathrm{NO}_{2}\right.$ $\left[\mathrm{VCO}_{2}\right.$ is $\mathrm{CO}_{2}$ output and $\mathrm{VO}_{2}$ is $\mathrm{O}_{2}$ uptake], and the ventilation equivalents for $\mathrm{O}_{2}(\dot{\mathrm{VE}} /$ $\mathrm{VO}_{2}$ ) were calculated for each expired air collection sample.

Subjects were measured at rest for $4 \mathrm{~min}$ while sitting on the bicycle ergometer. Subjects then performed a warm-up exercise for $4 \mathrm{~min}$, or until the heart rate reached 150 beats/minute, while the resistance of the bi- cycle pedal was maintained at moderate work load of $0.50-1.50 \mathrm{~kg} / \mathrm{min}$. At the completion of the warm-up period the workloads were increased in successive $1.5 \mathrm{~min}$ steps of 1 and $2 \mathrm{~kg} / \mathrm{min}$ until exhaustion, depending on the subject's ability. The last 30 -second samples of expired air were collected for determination of $\dot{\mathrm{VO}}_{2}$ and $\mathrm{VCO}_{2}$. Throughout the test the rate of oxygen consumption increased linearly with the magnitude of work, and as the exercising subject approached the point of exhaustion or fatigue, his/her oxygen consumption reached a maximum and remained at that level even with further increase in work.

\section{Estimates of occupational activity level}

The subjects were asked about their participation in organized sports (i.e., soccer, basketball, swimming, bicycling, tennis, and hiking). Each participant was specifically asked how many times per week he/she participated in an organized athletic activity. Based on this information, the subjects were classified into three groups. Low level: sedentary individuals who did not regularly practice any sport (although some subjects were occasionally involved in organized activities such as dance groups). Medium level: individuals who participated in organized sports on a given school or college team, but such activity took place less than 3 times per week. High level: individuals whose employment was characterized by a high level of daily activity (e.g., agricultural workers), or subjects who were members of organized sports teams at school or college and the activity occurred more than 3 times per week (e.g., basketball, swimming, and soccer team members).

\section{Statistical analysis}

The data were analyzed using parametric and non-parametric statistical tests. The variables that were not normally distributed were converted to z-scores (normalized) or logarithmic transformations in order to determine the statistical significance of the observed differences and inter-relationships. In addition, the data were evaluated using step-wise multiple regression analysis whereby the most important variables that 
TABLE 1. General characteristics of males and females included in the study of aerobic capacity during maximal exercise at high altitude

\begin{tabular}{|c|c|c|c|c|c|}
\hline \multirow[b]{2}{*}{ Variables } & \multicolumn{5}{|c|}{ Mean $\pm \mathrm{SE}$} \\
\hline & $\begin{array}{l}\text { High altitude } \\
\text { rural natives } \\
(\text { HARN })\end{array}$ & $\begin{array}{l}\text { High altitude } \\
\text { urban natives } \\
\text { (HAUN) }\end{array}$ & $\begin{array}{l}\text { Acclimatized } \\
\text { since birth } \\
\text { (AHAB) }\end{array}$ & $\begin{array}{l}\text { Acclimatized } \\
\text { during growth } \\
\text { (AHAG) }\end{array}$ & $\begin{array}{c}\text { Acclimatized } \\
\text { during adulthood } \\
(\mathrm{AH} \amalg \mathrm{AA})\end{array}$ \\
\hline \multicolumn{6}{|l|}{ Males } \\
\hline $\mathbf{N}$ & 39 & 32 & 33 & 25 & 25 \\
\hline Age (yr) & $34.72 \pm 1.31$ & $21.13 \pm 0.67^{*}$ & $21.36 \pm 1.04^{*}$ & $22.30 \pm 1.79 *$ & $31.18 \pm 1.70$ \\
\hline Age at arrival (yr) & n.a. & n.a. & n.a. & $8.54 \pm 0.83$ & $25.48 \pm 1.83$ \\
\hline Residence (yr) & $34.72 \pm 1.31$ & $21.13 \pm 0.69$ & $21.36 \pm 1.04$ & $13.74 \pm 2.03$ & $3.35 \pm 1.02$ \\
\hline Occupational activity (score) & $2.77 \pm 0.07$ & $2.06 \pm 0.09^{*}$ & $2.00 \pm 0.12^{*}$ & $2.56 \pm 0.14$ & $2.12 \pm 0.16^{*}$ \\
\hline Weight (kg) & $58.65 \pm 1.12$ & $60.04 \pm 1.04$ & $61.69 \pm 1.56$ & $64.44 \pm 1.90^{*, * *}$ & $69.77 \pm 2.09^{*, * *}$ \\
\hline Height $(\mathrm{cm})$ & $160.56 \pm 0.59$ & $168.54 \pm 0.83^{*}$ & $170.34 \pm 1.41^{*}$ & $174.29 \pm 1.32^{*, * *}$ & $172.94 \pm 1.68^{*}, * *$ \\
\hline BMI $\left(\mathrm{kg} / \mathrm{m}^{2}\right)$ & $22.73 \pm 0.38$ & $21.12 \pm 0.33$ & $21.19+0.39$ & $21.23 \pm 0.59$ & $23.30 \pm 0.60$ \\
\hline Sum of skinfolds (mm) & $41.97 \pm 2.19$ & $48.34 \pm 2.30$ & $46.42 \pm 2.92$ & $45.47 \pm 3.21$ & $52.38 \pm 4.36^{*}$ \\
\hline Bio-impedance $(\Omega)$ & $469.0 \pm 6.5$ & $546.0 \pm 13.1$ & $521.9 \pm 9.7$ & $522.0 \pm 11.2$ & $485.8 \pm 7.7$ \\
\hline Lean body weight (kg) & $50.09 \pm 0.82$ & $49.14 \pm 0.84$ & $51.21 \pm 1.17$ & $51.98 \pm 1.12$ & $56.36 \pm 1.53^{*}$ \\
\hline Fat weight $(\mathrm{kg})$ & $8.56 \pm 0.75$ & $10.94 \pm 0.61^{*}$ & $10.48 \pm 0.77^{*}$ & $12.47 \pm 1.22^{*}$ & $13.41 \pm 1.61^{*}$ \\
\hline Body fat $(\%)$ & $14.20 \pm 1.08$ & $17.95 \pm 0.84^{*}$ & $16.59 \pm 1.02^{*}$ & $18.69 \pm 1.39 *$ & $18.64 \pm 1.70^{*}$ \\
\hline Mean skin reflectance (\%) & $25.97 \pm 0.46$ & $32.67 \pm 0.33^{*}$ & $37.87 \pm 0.67^{*, * *}$ & $39.12 \pm 0.77^{*, * *}$ & $40.98 \pm 0.83^{*}, * *$ \\
\hline \multicolumn{6}{|l|}{ Fermales } \\
\hline $\mathrm{N}$ & & 35 & 32 & 25 & 18 \\
\hline Age (yr) & & $21.09 \pm 1.04$ & $19.61 \pm 0.82$ & $20.76 \pm 1.16$ & $32.22 \pm 1.67^{* *}$ \\
\hline Age at arrival (yr) & & n.a. & n.a. & $6.66 \pm 0.76$ & $26.94 \pm 1.99$ \\
\hline Residence (yr) & & $20.09 \pm 1.04$ & $19.61 \pm 0.82$ & $14.09 \pm 1.04$ & $5.08 \pm 1.56$ \\
\hline Occupational activity (score) & & $1.94 \pm 0.12$ & $1.94 \pm 0.13$ & $2.40 \pm 0.13$ & $2.33 \pm 0.18$ \\
\hline Weight (kg) & & $54.96 \pm 1.58$ & $53.08 \pm 1.19$ & $56.52 \pm 1.38^{* *}$ & $57.89 \pm 1.96^{* *}$ \\
\hline Height $(\mathrm{cm})$ & & $157.69 \pm 1.03$ & $157.76 \pm 1.13$ & $162.58 \pm 1.09^{* *}$ & $162.99 \pm 1.68^{* *}$ \\
\hline $\mathrm{BMI}\left(\mathrm{kg} / \mathrm{m}^{2}\right)$ & & $22.12 \pm 0.60$ & $21.28 \pm 0.35$ & $21.37 \pm 0.44$ & $21.74 \pm 0.59$ \\
\hline Bio-impedance $(\Omega)$ & & $585.6 \pm 10.0$ & $610.9 \pm 12.3$ & $580.2 \pm 12.5$ & $550.7 \pm 11.7$ \\
\hline Sum of skinfolds (mm) & & $69.57 \pm 3.45$ & $68.44 \pm 3.25$ & $62.96 \pm 2.79$ & $67.33 \pm 4.73$ \\
\hline Lean body weight (kg) & & $39.66 \pm 0.71$ & $38.38 \pm 0.95$ & $42.78 \pm 1.12^{* *}$ & $44.60 \pm 1.44^{* *}$ \\
\hline Fat weight (kg) & & $15.30 \pm 1.19$ & $14.69 \pm 0.84$ & $13.74 \pm 1.10$ & $13.30 \pm 0.91$ \\
\hline Body fat $(\%)$ & & $26.91 \pm 1.32$ & $27.43 \pm 1.30$ & $23.97 \pm 1.63$ & $22.73 \pm 1.18$ \\
\hline Mean skin reflectance $(\%)$ & & $33.21 \pm 0.35$ & $36.06 \pm 0.60^{* *}$ & $37.14 \pm 0.77^{* *}$ & $40.72 \pm 0.70^{* *}$ \\
\hline
\end{tabular}

* Significantly $(P<0.05)$ different from HARN

** Significantly $(P<0.01)$ different from HAUN.

influenced variability in aerobic capacity were selected from several independent variables.

\section{RESULTS}

\section{Physical characteristics}

As shown in Table 1, the high altitude urban natives and the Bolivians of foreign ancestry acclimatized to high altitude since birth or during growth were significantly younger than both the high altitude rural natives and the non-Bolivians acclimatized to high altitude during adulthood. In terms of body size and composition, the high altitude rural subjects were significantly shorter, leaner (indicated by lesser skinfold thicknesses and percent body fat), and darker (i.e., lower mean skin reflectance values) than the other four groups. However, the subjects acclimatized to high altitude since birth or during growth and accli- matized to high altitude during adulthood were very similar in skin color. Among females, both the high altitude urban natives and those acclimatized to high altitude since birth were significantly shorter than their counterparts acclimatized to high altitude during growth or during adulthood. On the other hand, there were no differences in body fat among females in all groups. In contrast, the female subjects acclimatized to high altitude since birth or during growth and those acclimatized during adulthood had similar skin reflectance values, but all three groups were significantly lighter than the high altitude urban natives.

\section{Bioenergetics}

Table 2 summarizes the results of the male and female bioenergetic tests. These data show that among males the arterial oxygen saturation (\%) of the subjects acclima- 
TABLE 2. Bioenergetic values of high altitude rural natives (HARN), high altitude urban natives (HAUN), Bolivians of foreign ancestry acclimatized to high altitude since birth (AHAB), Bolivians of foreign ancestry acclimatized to high altitude during growth (AHAG), and foreigners acclimatized to high altitude during adulthood (AHAA)

\begin{tabular}{|c|c|c|c|c|c|}
\hline \multirow[b]{2}{*}{ Variables } & \multicolumn{5}{|c|}{ Mean \pm SE } \\
\hline & $\begin{array}{c}\text { High Altitude } \\
\text { Rural Native } \\
\text { s (HARN) }\end{array}$ & $\begin{array}{c}\text { High Altitude } \\
\text { Urban Natives } \\
\text { (HAUN) }\end{array}$ & $\begin{array}{l}\text { Acclimatized } \\
\text { Since Birth } \\
\text { (AHAB) }\end{array}$ & $\begin{array}{l}\text { Acclimatized } \\
\text { During Growth } \\
\text { (AHAG) }\end{array}$ & $\begin{array}{c}\text { Acclimatized } \\
\text { During Adulthood } \\
\text { (AHAA) }\end{array}$ \\
\hline \multicolumn{6}{|l|}{ Males } \\
\hline $\mathrm{N}$ & 39 & 32 & 33 & 25 & 25 \\
\hline $\mathrm{SaO}_{2}(\%)$ & $91.00 \pm 0.24$ & $90.10 \pm 0.34$ & $88.38 \pm 0.50^{*}$ & $88.44 \pm 0.52^{*}$ & $88.88 \pm 0.65^{*}$ \\
\hline Heart rate (beats/min) & $167.28 \pm 2.16$ & $183.59 \pm 1.83^{*}$ & $179.76 \pm 1.96^{*}$ & $178.84 \pm 2.96^{*}$ & $171.75 \pm 2.61 *$ \\
\hline$\dot{\mathrm{V}} \mathrm{E}_{(\mathrm{BTPS})}(\mathrm{L} / \mathrm{min})$ & $119.35 \pm 3.10$ & $122.65 \pm 3.26$ & $122.26 \pm 4.62$ & $123.93 \pm 3.50$ & $132.29 \pm 6.05^{*}$ \\
\hline $\mathrm{VO}_{2} \mathrm{STPD}(\mathrm{L} / \mathrm{min})$ & $2.81 \pm 0.05$ & $2.39 \pm 0.05^{*}$ & $2.49 \pm 0.08^{*}$ & $2.73 \pm 0.06$ & $2.55 \pm 0.12^{*}$ \\
\hline $\mathrm{VO}_{2} \mathrm{STPD}(\mathrm{ml} / \mathrm{min} / \mathrm{kg})$ & $48.24 \pm 0.95$ & $40.00 \pm 0.75^{*}$ & $40.43 \pm 0.83^{*}$ & $42.95 \pm 1.21 *$ & $36.69 \pm 1.54^{*}$ \\
\hline $\mathrm{VO}_{2} \mathrm{STPD}(\mathrm{ml} / \mathrm{min} / \mathrm{kg} \cdot \mathrm{LBM})$ & $56.21 \pm 1.11$ & $48.92 \pm 0.90^{*}$ & $48.63 \pm 1.04^{*}$ & $52.90 \pm 1.26$ & $44.97 \pm 1.62^{*}$ \\
\hline $\mathrm{VCO}_{2} \operatorname{STPD}(\mathrm{L} / \mathrm{min})$ & $2.81 \pm 0.09$ & $2.73 \pm 0.06$ & $2.82 \pm 0.09$ & $2.87 \pm 0.09$ & $2.75 \pm 0.13$ \\
\hline$\dot{\mathrm{V} C O}(\mathrm{ml} / \mathrm{min} / \mathrm{kg})$ & $48.10 \pm 1.29$ & $45.64 \pm 1.02$ & $45.58 \pm 1.00$ & $45.06 \pm 1.52$ & $39.80 \pm 2.22^{*}$ \\
\hline RQ & $1.01 \pm 0.03$ & $1.14 \pm 0.02^{*}$ & $1.13 \pm 0.02 *$ & $1.05 \pm 0.03$ & $1.10 \pm 0.04^{*}$ \\
\hline $\mathrm{VE}_{\text {(BTPS })} / \mathrm{VO}_{2}$ & $42.81 \pm 1.17$ & $51.81 \pm 1.23^{*}$ & $49.49 \pm 1.39^{*}$ & $45.57 \pm 1.17$ & $52.78 \pm 1.81 *$ \\
\hline $\mathrm{VO}_{2} / \mathrm{HR}$ (beats $/ \mathrm{min}$ ) & $16.88 \pm 0.37$ & $13.04 \pm 0.32^{*}$ & $13.90 \pm 0.51^{*}$ & $15.39 \pm 0.46^{*}$ & $15.17 \pm 0.81^{*}$ \\
\hline \multicolumn{6}{|l|}{ Females } \\
\hline $\mathbf{N}$ & & 36 & 32 & 24 & 18 \\
\hline $\mathrm{SaO}_{2}(\%)$ & & $90.97 \pm 0.42$ & $89.94 \pm 0.62$ & $89.68 \pm 0.70$ & $88.78 \pm 0.76^{* *}$ \\
\hline Heart rate (beats/min) & & $173.74 \pm 2.62$ & $179.25 \pm 2.34$ & $172.28 \pm 2.93$ & $164.39 \pm 3.34^{* *}$ \\
\hline$\dot{V} \mathbf{E}_{(\mathrm{BTPS})}(\mathrm{L} / \mathrm{min})$ & & $78.75 \pm 2.55$ & $77.92 \pm 2.87$ & $83.78 \pm 2.68$ & $88.86 \pm 5.88^{* *}$ \\
\hline VO. STPD (L/min) & & $1.66 \pm 0.06$ & $1.60 \pm 0.06$ & $1.78 \pm 0.07$ & $1.60 \pm 0.08$ \\
\hline$\dot{\mathrm{VO}}_{2} \mathrm{STPD}(\mathrm{ml} / \mathrm{min} / \mathrm{kg})$ & & $30.60 \pm 1.04$ & $30.15 \pm 0.94$ & $31.68 \pm 1.09$ & $27.53 \pm 0.93$ \\
\hline $\mathrm{VO}_{2} \mathrm{STPD}(\mathrm{ml} / \mathrm{min} / \mathrm{kg}-\mathrm{LBM})$ & & $41.98 \pm 1.34$ & $41.69 \pm 1.19$ & $41.82 \pm 1.32$ & $35.66 \pm 1.12^{* * *}$ \\
\hline VCO $_{2}$ STPD $(\mathrm{L} / \mathrm{min})$ & & $1.87 \pm 0.05$ & $1.76 \pm 0.07$ & $1.93 \pm 0.09$ & $1.66 \pm 0.09$ \\
\hline$\dot{\mathrm{V} C O}(\mathrm{ml} / \mathrm{min} / \mathrm{kg})$ & & $34.45 \pm 0.99$ & $33.36 \pm 1.05$ & $34.33 \pm 1.45$ & $28.67 \pm 1.34^{* * *}$ \\
\hline $\mathbf{R Q}$ & & $1.13 \pm 0.02$ & $1.11 \pm 0.01$ & $1.08 \pm 0.02$ & $1.04 \pm 0.04^{* *}$ \\
\hline $\mathrm{VE}_{(\mathrm{BTPS})} / \mathrm{NO}_{2}$ & & $48.14 \pm 1.37$ & $49.55 \pm 1.55$ & $47.71 \pm 1.42$ & $55.99 \pm 3.16^{* *}$ \\
\hline VO. $/ \mathrm{HR}$ (beats/min) & & $9.63 \pm 0.37$ & $8.97 \pm 0.40$ & $10.49 \pm 0.52$ & $9.80 \pm 0.56$ \\
\hline
\end{tabular}

* Significantly $(P<0.05)$ different from high altitude rural natives (HARN).

** Significantly $(P<0.05)$ different from high altitude urban natives (HAUN)

${ }^{* * *}$ Significantly $(P<0.01)$ different from high altitude urban natives (HAUN).

tized to high altitude during adulthood was significantly lower than that of the high altitude rural natives. The heart rate among the high altitude rural natives was significantly lower than that of the high altitude urban natives acclimatized to high altitude since birth or during growth, but was similar to that of the group which was acclimatized to high altitude during adulthood. The mean pulmonary ventilation for those acclimatized to high altitude during adulthood was significantly higher than those of the high altitude rural natives; however, the subjects acclimatized to high altitude since birth or during growth had similar values.

The Bolivians of foreign ancestry acclimatized to high altitude since birth or during growth and the high altitude urban natives attained lower aerobic capacity $(40-43 \mathrm{ml}$ $\mathrm{min} / \mathrm{kg}$ ) than the high altitude rural natives $(48 \mathrm{ml} / \mathrm{min} / \mathrm{kg})$. On the other hand, subjects acclimatized to high altitude since birth or during growth and high altitude urban sam- ples had significantly higher aerobic capacity $(40-43 \mathrm{ml} / \mathrm{min} / \mathrm{kg})$ than those acclimatized to high altitude during adulthood (37 $\mathrm{ml} / \mathrm{min} / \mathrm{kg}$ ). These group similarities and differences did not change when the maximum oxygen consumption was related to lean body mass. The fact that in all the samples the RQ was $>1$ suggests that the subjects did reach maximum exertion.

Among females the arterial oxygen saturation (\%) and heart rate of the non-Bolivians acclimatized to high altitude during adulthood was significantly lower than those of the high altitude urban natives. Similarly, Bolivians of foreign ancestry acclimatized to high altitude during birth or during growth and high altitude urban natives attained higher aerobic capacity than non-Bolivians acclimatized to high altitude during adulthood. The ventilation equivalent of the non-Bolivians acclimatized to high altitude during adulthood was significantly higher than the other three samples. 
As with the males, all four female groups exhibited an $R Q>1$ which suggests that the subjects did reach maximum exertion.

\section{DISCUSSION}

The higher oxygen consumption observed among the high altitude rural natives agrees with previous studies conducted among rural high altitude samples (Baker, 1976; Buskirk, 1976; Greksa et al., 1984; Kollias et al., 1968; Lahiri et al., 1967; Mazess, 1969; Sun et al., 1990; Way, 1976). Similarly, the $\mathrm{VO}_{2}$ max observed among the high altitude rural natives and those acclimatized to high altitude since birth or during growth is comparable to that found among urban samples studied at high altitude (Coudert, 1993; Fellman, 1986; Frisancho et al., 1973; Greksa and Haas, 1982; Greksa et al., 1981; 1985; Mazess, 1969). The fact that the Bolivians of foreign ancestry acclimatized to high altitude since birth or during growth attained comparable values to those of the high altitude urban natives suggests that the attainment of normal aerobic capacity at high altitude is related to developmental acclimatization.

\section{Aerobic capacity and developmental response}

It is usually assumed that the expression of $\mathrm{VO}_{2}$ max in terms of $\mathrm{ml} / \mathrm{min}$ per $\mathrm{kg}$ of body weight is a good indicator of aerobic work capacity. In general, however, one would expect that among samples where there is large variability in body composition, maximum oxygen consumption expressed as $\mathrm{ml}$ $\mathrm{min} / \mathrm{kg}$ is not an adequate indicator of aerobic capacity. Analysis of the relationship of body composition and aerobic capacity indicated that the latter is negatively influenced by body fat within each sample. Table 3 presents the average correlations for all samples. These data show that aerobic capacity, expressed as $\mathrm{L} / \mathrm{min}$ or as $\mathrm{ml} / \mathrm{min} / \mathrm{kg}$ of lean body mass, is a better index for aerobic capacity than $\mathrm{ml} / \mathrm{min} / \mathrm{kg}$ of total body weight. Therefore, $\mathrm{V}_{2}$ max, expressed in terms of $\mathrm{ml} / \mathrm{min} / \mathrm{kg}$ of lean body mass, is a better indicator of aerobic capacity than $\mathrm{VO}_{2}$ max expressed as $\mathrm{ml} / \mathrm{min} / \mathrm{kg}$ of total body weight.

As illustrated in Figure 1, among Bolivians of foreign ancestry acclimatized to high
TABLE 3. Summary of correlation coefficients ( $r$ ) of estimates of body fat and measures of aerobic capacity during maximal exercise at high altitude of five male and female samples

\begin{tabular}{lrr}
\hline Variables & $\begin{array}{c}\text { Males } \\
(\mathrm{r})\end{array}$ & $\begin{array}{c}\text { Females } \\
(\mathrm{r})\end{array}$ \\
\hline $\mathrm{VO}_{2}(\mathrm{~L} / \mathrm{min})$ & & \\
Sum of skinfolds (mm) & -0.03 & 0.07 \\
Fat weight $(\mathrm{kg})$ & 0.08 & 0.14 \\
$\%$ fat weight $(\%)$ & -0.07 & -0.05 \\
$\mathrm{VO}_{2}(\mathrm{ml} / \mathrm{min} / \mathrm{kg})$ & & \\
Sum of skinfolds $(\mathrm{mm})$ & $-0.50^{*}$ & $-0.36^{*}$ \\
Fat weight $(\mathrm{kg})$ & $-0.50^{*}$ & $-0.36^{*}$ \\
$\%$ fat weight $(\%)$ & $-0.46^{*}$ & $-0.35^{*}$ \\
$\mathrm{VO}_{2}(\mathrm{ml} / \mathrm{min} / \mathrm{kg}-\mathrm{LBM})$ & & \\
Sum of skinfolds $(\mathrm{mm})$ & -0.24 & 0.02 \\
Fat weight $(\mathbf{k g})$ & -0.02 & 0.16 \\
\% fat weight $(\%)$ & 0.06 & 0.23 \\
\hline
\end{tabular}

$* P<0.01$.

altitude during development, about $25 \%$ of the variability in aerobic capacity can be explained by age at arrival to high altitude. It should be noted that age at migration was not correlated with chronological age $(r=$ 0.14 ). This finding is in agreement with a previous study conducted among sea-level Peruvian college students raised at high altitude (Frisancho et al., 1975). However, this outcome differs from the results of Greksa and Haas (1982) who studied U.S. children raised in $\mathrm{La} \mathrm{Paz}$, Bolivia. In this study it should be noted that the relationship of age at migration to high altitude and aerobic capacity was evaluated with reference to oxygen consumption per $\mathrm{ml}$ per min per kilogram of total body weight and work output, indices which are highly influenced by body composition and training. The results of the present study also disagree with the findings of Sun et al. (1990) who conducted comparative studies of Tibetan natives and Han Chinese who were lifelong sea-level residents residing at high altitude. In this study the aerobic capacity (maximum oxygen intake) of high altitude native Tibetans was higher than the Han Chinese who were born at sea-level and acclimatized to high altitude after the age of 8 years (Sun et al., 1990). However, this research included a higher proportion of Han smokers (45\%) than Tibetan smokers (38\%). Studies conducted in La Paz, Bolivia, indicate that the negative effects of smoking on aerobic capacity are greater at high altitude than at 


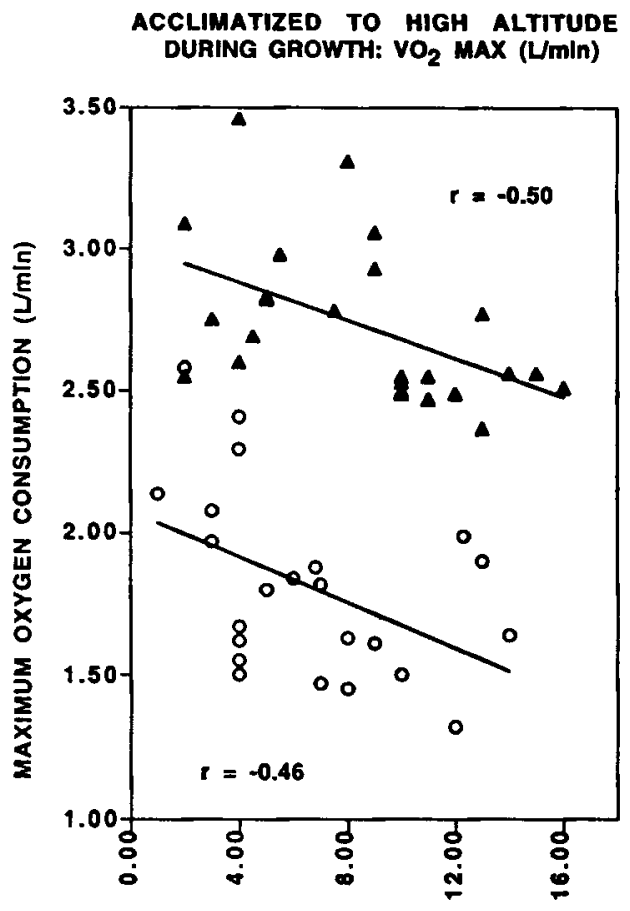

AGE AT ARRIVAL TO HIGH ALTITUDE (YRS)

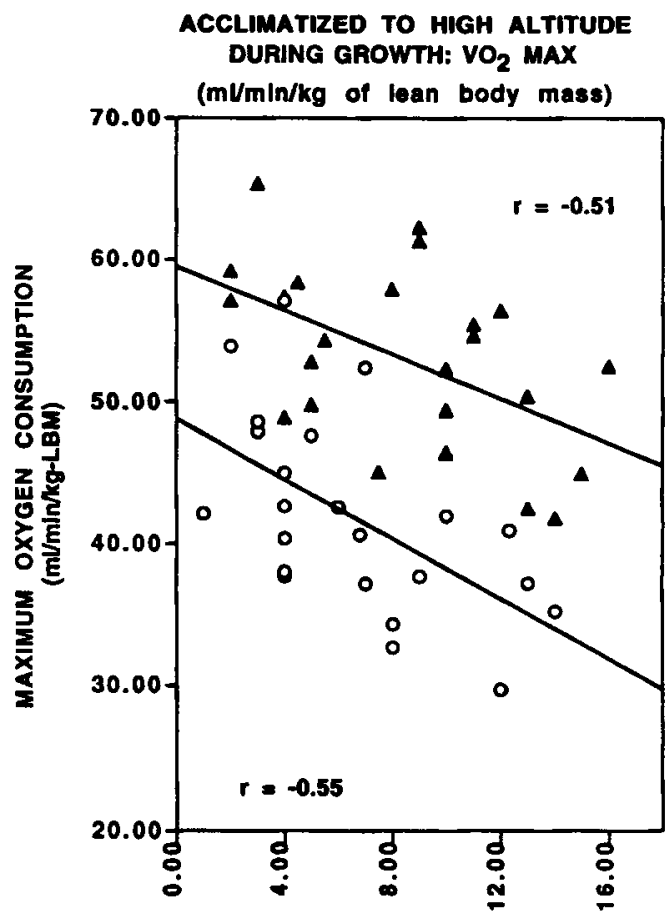

AGE AT ARRIYAL TO HIGH ALtitude (YRS)

Fig. 1. Relationship of age at arrival to high altitude and aerobic capacity. $\Delta=\mathrm{Males} \mathrm{VO}_{2} \mathrm{max}$ $(\mathrm{l} / \mathrm{min})=-0.033 \mathrm{x}+3.013 ; \quad \mathrm{r}=-0.50 ; \quad \mathrm{VO}_{2} \max (\mathrm{L} / \mathrm{min} / \mathrm{kg}-\mathrm{LBM})=-0.772 \mathrm{x}+59.488, \quad \mathrm{r}=-0.51$. $\mathrm{O}=$ Females: $\mathrm{VO}_{2} \max (\mathrm{l} / \mathrm{min})=-0.040 \mathrm{x}+2.077, \mathrm{r}=-0.46 ; \quad \mathrm{VO}_{2} \max (\mathrm{I} / \mathrm{min} / \mathrm{kg}-\mathrm{LBM})=-1.059 \times$ $+48.854, r=-0.55]$. Note: In both males and females maximum oxygen consumption is inversely related to age at migration.

sea level (Spielvogel et al., 1988). Therefore, the lower aerobic capacity of the Han probably reflects the negative effects of smoking rather than differences in the process of acclimatization to high altitude. In other words, if the comparison had either excluded all smokers or balanced the samples by having the same proportion of smokers in the Tibetan and Han samples, the sea-level Han would have attained a similar aerobic capacity as the high-altitude Tibetan natives. This result would have suggested a developmental role in the attainment of full functional adaptation to high altitude.

\section{Aerobic capacity and genetics}

\section{Skin reflectance}

Previous studies have demonstrated that skin color, as measured by skin reflectance, is under genetic control (Harrison, 1961). It has been shown that variability in skin color reflectance is the result of the additive effects of 3-5 loci (Byard, 1981) and that 50 to $70 \%$ of the variability in skin reflectance is due to a heritable additive genetic component (Frisancho et al., 1981; Post and Rao, 1977). Based on this information Greksa (1992) has used measurements of skin reflectance to evaluate the role of genetic factors in the acquisition of lung volumes of high altitude subjects. As such, skin reflectance can be used as a proximate marker of genetic differences.

As shown in Table 4 in both the high altitude rural and urban natives, 15 to $25 \%$ of the variability in aerobic capacity is influenced by genetic factors associated with skin color reflectance (Fig. 2). On the other hand, skin color reflectance does not seem to influence the aerobic capacity of Bolivians of for- 
TABLE 4. Correlation coefficients ( $r$ ) of log mean skin reflectance (\%) and measures of aerobic capacity during maximal exercise at high altitude in males and females

\begin{tabular}{|c|c|c|c|c|c|c|c|c|c|c|}
\hline \multirow[b]{2}{*}{ Variables } & \multicolumn{2}{|c|}{$\begin{array}{l}\text { High altitude } \\
\text { rural natives } \\
\text { (HARN) }\end{array}$} & \multicolumn{2}{|c|}{$\begin{array}{l}\text { High altitude } \\
\text { urban natives } \\
\text { (HAUN) }\end{array}$} & \multicolumn{2}{|c|}{$\begin{array}{l}\text { Acclimatized } \\
\text { since birth } \\
\text { (AHAB) }\end{array}$} & \multicolumn{2}{|c|}{$\begin{array}{l}\text { Acclimatized } \\
\text { during growth } \\
\text { (AHAG) }\end{array}$} & \multicolumn{2}{|c|}{$\begin{array}{c}\text { Acclimatized } \\
\text { during adulthood } \\
\text { (AHAA) }\end{array}$} \\
\hline & $\begin{array}{l}\mathbf{M} \\
(\mathbf{r})\end{array}$ & $\begin{array}{c}\mathbf{F} \\
(\mathbf{r})\end{array}$ & $\begin{array}{l}\mathbf{M} \\
(\mathbf{r})\end{array}$ & $\begin{array}{c}\mathbf{F} \\
(\mathrm{r} 0\end{array}$ & $\begin{array}{c}\mathbf{M} \\
(\mathbf{r})\end{array}$ & $\begin{array}{c}\mathbf{F} \\
(\mathbf{r})\end{array}$ & $\begin{array}{l}\mathbf{M} \\
(\mathrm{r})\end{array}$ & $\begin{array}{c}\mathbf{F} \\
(\mathbf{r})\end{array}$ & $\begin{array}{l}\mathrm{M} \\
(\mathrm{r})\end{array}$ & $\begin{array}{c}\mathbf{F} \\
(\mathbf{r})\end{array}$ \\
\hline $\begin{array}{l}\mathrm{VO}_{2} \mathrm{STPD}(\mathrm{L} / \mathrm{min}) \\
\quad \text { Log skin reflectance }(\%)\end{array}$ & $-0.36^{*}$ & - & $-0.25^{* * *}$ & $-0.37^{* *}$ & -0.02 & -0.09 & -0.10 & -0.004 & 0.11 & -0.05 \\
\hline $\begin{array}{l}\mathrm{VO}_{2} \text { STPD }(\mathrm{ml} / \mathrm{min} / \mathrm{kg}) \\
\text { Log skin reflectance }(\%) \\
\dot{\mathrm{VO}} \text { STPD }(\mathrm{ml} / \mathrm{min} / \mathrm{kg}-\mathrm{LBM})\end{array}$ & $-0.39^{*}$ & - & $-0.33^{*}$ & $-0.41^{* *}$ & -0.24 & 0.13 & 0.03 & -0.11 & 0.04 & -0.16 \\
\hline Log skin reflectance $(\%)$ & $-0.52^{*}$ & - & $-0.40^{*}$ & $-0.44^{*}$ & -0.14 & 0.11 & -0.001 & -0.11 & -0.09 & -0.19 \\
\hline
\end{tabular}

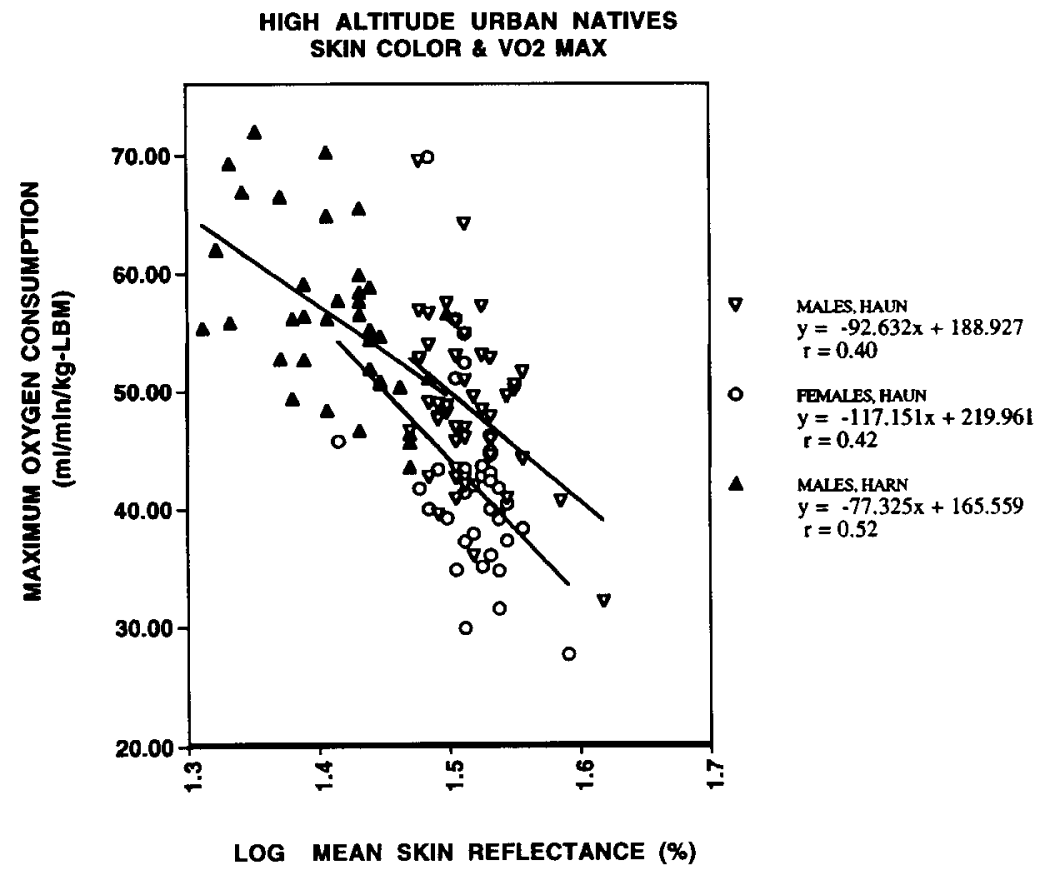

Fig. 2. Relationship of skin reflectance color and aerobic capacity. Note: The inverse relationship between skin color and aerobic capacity in high altitude urban and rural natives.

eign ancestry acclimatized to high altitude since birth, during growth, or during adulthood. Since genetic factors do influence the attainment of aerobic capacity at sea level (Klissouras et al., 1973), the lack of association between skin reflectance and aerobic capacity is probably related to the fact that the Bolivians of foreign ancestry were selected specifically so as not to include subjects with indigenous admixture.

\section{Sibling similarities}

Twin studies at sea level indicate that aerobic capacity is under strong genetic control (Klissouras et al., 1973). As shown in Table 5, among the subjects acclimatized to high altitude either since birth or during growth, the sibling correlation coefficients for aerobic capacity are significant. Although it is not statistically significant 
TABLE 5. Sibling correlation (r) coefficients in measurements of aerobic capacity among high altitude urban natives (HAUN) and samples acclimatized to high altitude since birth (AHAB) or during growth (AHAG)

\begin{tabular}{lcccc}
\hline & & \multicolumn{2}{c}{ Maximum oxygen consumption $(\mathbf{r})$} \\
\cline { 2 - 4 } & No. pairs & L/min & $\mathrm{ml} / \mathrm{min} / \mathrm{kg}$ & $\mathrm{ml} / \mathrm{min} / \mathrm{kg} \mathrm{of} \mathrm{LBM}$ \\
\hline HAUN & 7 & 0.23 & 0.34 & 0.37 \\
AHAB \& AHAG & 22 & $0.49^{*}$ & $0.51^{*}$ & $0.50^{*}$ \\
\hline
\end{tabular}

* Significantly $(P<0.01)$.

TABLE 6. Aerobic capacity by occupational activity level among five male samples studied in La Paz, Bolivia

\begin{tabular}{|c|c|c|c|c|c|}
\hline \multirow[b]{2}{*}{$\begin{array}{l}\text { Occupational } \\
\text { activity level }\end{array}$} & \multicolumn{5}{|c|}{ Mean \pm SE } \\
\hline & $\begin{array}{c}\text { High altitude } \\
\text { rural natives } \\
\text { (HARN) } \\
(\mathrm{N}=39)\end{array}$ & $\begin{array}{c}\text { High altitude } \\
\text { urban natives } \\
\text { (HAUN) } \\
(\mathbf{N}=32)\end{array}$ & $\begin{array}{l}\text { Acclimatized } \\
\text { since birth } \\
(\mathrm{AHAB}) \\
(\mathrm{N}=\mathbf{3 3})\end{array}$ & $\begin{array}{c}\text { Acclimatized } \\
\text { during growth } \\
\text { (AHAG) } \\
(\mathrm{N}=25)\end{array}$ & $\begin{array}{c}\text { Acclimatized } \\
\text { during adulthood } \\
\text { (AHAA) } \\
(\mathrm{N}=25)\end{array}$ \\
\hline \multicolumn{6}{|c|}{$\dot{\mathrm{VO}}_{2}$ STPD $(\mathrm{L} / \mathrm{min})$} \\
\hline Low & - & $2.01 \pm 0.09$ & $2.25 \pm 0.12$ & $2.73 \pm 0.07$ & $1.85 \pm 0.25$ \\
\hline Medium & $2.63 \pm 0.12$ & $2.39 \pm 0.05$ & $2.47 \pm 0.10$ & $2.88 \pm 0.17$ & $2.55 \pm 0.10$ \\
\hline High & $2.86 \pm 0.06$ & $2.67 \pm 0.09$ & $2.78 \pm 0.16$ & $2.68 \pm 0.07$ & $3.01 \pm 0.15$ \\
\hline Significance & $P<0.05$ & $P<0.01$ & $P<0.01$ & $P<0.01$ & $P<0.01$ \\
\hline \multicolumn{6}{|c|}{$\dot{\mathrm{VO}}_{2} \mathrm{STPD}(\mathrm{ml} / \mathrm{min} / \mathrm{kg})$} \\
\hline Low & - & $32.41 \pm 1.49$ & $34.31 \pm 0.65$ & $37.48 \pm 1.81$ & $25.38 \pm 2.37$ \\
\hline Medium & $41.88 \pm 0.80$ & $39.68 \pm 0.41$ & $40.09 \pm 0.49$ & $38.23 \pm 1.76$ & $37.32 \pm 0.79$ \\
\hline High & $50.14 \pm 0.97$ & $46.59 \pm 0.83$ & $47.26 \pm 0.87$ & $45.30 \pm 1.35$ & $43.53 \pm 0.31$ \\
\hline Significance & $P<0.01$ & $P<0.01$ & $P<0.01$ & $P<0.01$ & $P<0.01$ \\
\hline \multicolumn{6}{|c|}{$\mathrm{VO}_{2}$ STPD $(\mathrm{ml} / \mathrm{min} / \mathrm{kg}-\mathrm{LBM})$} \\
\hline Low & - & $40.18 \pm 1.24$ & $42.24 \pm 1.10$ & $47.91 \pm 1.44$ & $35.70 \pm 3.96$ \\
\hline Medium & $48.70 \pm 1.23$ & $48.36 \pm 0.65$ & $49.21 \pm 1.22$ & $50.24 \pm 2.93$ & $44.95 \pm 1.07$ \\
\hline High & $58.46 \pm 1.11$ & $56.28 \pm 1.47$ & $53.81+1.74$ & $54.56+1.50$ & $51.17 \pm 1.07$ \\
\hline Significance & $P<0.01$ & $P<0.01$ & $P<0.01$ & $P<0.01$ & $P<0.01$ \\
\hline
\end{tabular}

within the high altitude urban natives there is a positive relationship in the aerobic capacity of siblings. These data suggest that in general 13 to $25 \%$ of the variability in aerobic capacity at high altitude can be explained by genetic factors shared by siblings. This lower correlation can be explained by the fact that the data are based on few number of siblings and not twins.

\section{Aerobic capacity and occupational activity}

Tables 6 and 7 compare aerobic capacity by occupational activity level for males and females. These data show that in both males and females there is a direct relationship between occupational activity level and aerobic capacity so that the higher the occupational activity level, the higher the aerobic capacity. Comparing these data with the results presented in Table 2 , it is evident that male high altitude urban natives and Bolivians acclimatized to high altitude since birth or during growth with a high level of occupational activity have aerobic capacity values that are similar to the average aerobic capacity of the high altitude rural native samples. These findings suggest that observed differences in aerobic capacity between either the high altitude urban natives or the Bolivians of foreign ancestry acclimatized to high altitude since birth or during growth are related to differences in occupational activity level. In contrast, the non-Bolivians acclimatized to high altitude during adulthood exhibiting a high occupational activity level attained a significantly lower aerobic capacity than the high altitude urban natives (presented in Table 2). Similarly, in both males and females at the same occupational activity level, the Bolivians acclimatized to high altitude during adulthood attained significantly lower aerobic capacity values than the high altitude urban natives or those acclimatized to high altitude since birth or during growth. These findings indicate high activity among individuals acclimatized to high altitude during adulthood is not sufficient to equal the adaptation acquired during growth. 
TABLE 7. Aerobic capacity by occupational activity level among four female samples studied in La Paz, Bolivia

\begin{tabular}{|c|c|c|c|c|}
\hline \multirow[b]{2}{*}{$\begin{array}{l}\text { Occupational } \\
\text { activity level }\end{array}$} & \multicolumn{4}{|c|}{ Mean \pm SE } \\
\hline & $\begin{array}{c}\text { High altitude } \\
\text { urban natives } \\
\text { (HAUN) } \\
(\mathrm{N}=36)\end{array}$ & $\begin{array}{c}\text { Acclimatized } \\
\text { since birth } \\
\text { (AHAB) } \\
(\mathrm{N}=32) \\
\end{array}$ & $\begin{array}{c}\text { Acclimatized } \\
\text { during growth } \\
(\mathrm{AHAG}) \\
(\mathrm{N}=24) \\
\end{array}$ & $\begin{array}{c}\text { Acclimatized } \\
\text { during adulthooc } \\
\text { (AHAA) } \\
(\mathrm{N}=18) \\
\end{array}$ \\
\hline \multicolumn{5}{|c|}{$\dot{\mathrm{V}} \mathrm{O}_{2} \mathrm{STPD}(\mathrm{L} / \mathrm{min})$} \\
\hline Low & $1.45 \pm 0.07$ & $1.39 \pm 0.04$ & $1.56 \pm 0.06$ & $1.16 \pm 0.14$ \\
\hline Medium & $1.64 \pm 0.06$ & $1.54 \pm 0.03$ & $1.74 \pm 0.10$ & $1.59 \pm 0.12$ \\
\hline High & $1.96 \pm 0.17$ & $2.00 \pm 0.21$ & $1.86 \pm 0.10$ & $1.75 \pm 0.09$ \\
\hline Significance & $P<0.01$ & $P<0.01$ & $P<0.01$ & $P<0.01$ \\
\hline \multicolumn{5}{|c|}{$\dot{\mathrm{VO}}_{2} \mathrm{STPD}(\mathrm{ml} / \mathrm{min} / \mathrm{kg})$} \\
\hline Low & $24.12 \pm 0.85$ & $25.30 \pm 0.47$ & $26.92 \pm 1.50$ & $21.57 \pm 2.04$ \\
\hline Medium & $30.71 \pm 0.52$ & $29.21 \pm 0.40$ & $30.69 \pm 1.16$ & $26.38 \pm 0.25$ \\
\hline High & $38.45 \pm 2.08$ & $38.53+1.51$ & $33.38 \pm 1.89$ & $30.29 \pm 0.87$ \\
\hline Significance & $P<0.01$ & $P<0.01$ & $P<0.01$ & $P<0.01$ \\
\hline \multicolumn{5}{|c|}{ VO ${ }_{2}$ STPD $(\mathrm{ml} / \mathrm{min} / \mathrm{kg}-\mathrm{LBM})$} \\
\hline Low & $35.65 \pm 1.68$ & $36.59 \pm 1.33$ & $37.87 \pm 0.15$ & $28.25 \pm 2.61$ \\
\hline Medium & $42.37 \pm 1.22$ & $41.04 \pm 1.20$ & $39.31 \pm 1.66$ & $34.73 \pm 0.94$ \\
\hline High & $49.07 \pm 3.47$ & $49.72 \pm 2.33$ & $44.78 \pm 2.02$ & $38.75 \pm 0.92$ \\
\hline Significance & $P<0.01$ & $P<0.01$ & $P<0.01$ & $P<0.01$ \\
\hline
\end{tabular}

TABLE 8. Comparison of aerobic capacity between Bolivians of foreign ancestry acclimatized to high altitude before the age of 9 years and those who were acclimatized after the age of 10 years from the same (high) occupational activity level

\begin{tabular}{|c|c|c|c|c|c|}
\hline \multicolumn{3}{|c|}{ Males } & \multicolumn{3}{|c|}{ Females } \\
\hline $\begin{array}{l}\text { Age (yr) of arrival } \\
\text { to high altitude }\end{array}$ & $\mathbf{N}$ & Mean $\pm \mathrm{SE}$ & $\begin{array}{l}\text { Age (yr) of arrival } \\
\text { to high altitude }\end{array}$ & $\mathbf{N}$ & Mean $\pm \mathrm{SE}$ \\
\hline \multicolumn{6}{|l|}{$\dot{\mathrm{V}} \mathrm{O}_{2}(\mathrm{~L} / \mathrm{min})$} \\
\hline $2-9$ & 7 & $2.91 \pm 0.10^{*}$ & $1-9$ & 7 & $2.01 \pm 0.13^{*}$ \\
\hline $10-16$ & 10 & $2.52 \pm 0.03$ & $10-14$ & 5 & $1.65 \pm 0.14$ \\
\hline \multicolumn{6}{|l|}{$\dot{\mathrm{V}} \mathrm{O}_{2}(\mathrm{ml} / \mathrm{min} / \mathrm{kg})$} \\
\hline $2-9$ & 7 & $49.04 \pm 2.17^{*}$ & $1-9$ & 7 & $36.38 \pm 2.24^{*}$ \\
\hline $10-16$ & 10 & $42.69 \pm 1.22$ & $10-14$ & 5 & $28.55 \pm 1.75$ \\
\hline \multicolumn{6}{|l|}{$\dot{\mathrm{v}} \mathrm{O}_{2}(\mathrm{ml} / \mathrm{min} / \mathrm{kg})$} \\
\hline $2-9$ & 7 & $60.19 \pm 1.11^{*}$ & $1-9$ & 7 & $48.85 \pm 2.33^{*}$ \\
\hline $10-16$ & 10 & $50.61 \pm 1.41$ & $10-14$ & 5 & $39.09 \pm 1.25$ \\
\hline
\end{tabular}

$* P<0.01$.

\section{Developmental response and occupational activity}

Table 8 presents the aerobic capacity of Bolivians to foreign ancestry acclimatized to high altitude before the age of 9 years versus those who were acclimatized after the age of 10 years from the same (high) occupational activity level. These data show that the individuals who maintained a high occupational activity level had a higher aerobic capacity if they were acclimatized to high altitude before the age of 9 years than if they had been acclimatized after the age of 10 . In other words, the effects of maintaining a high activity level on the attainment of high aerobic capacity is mediated by age at arrival to high altitude.

\section{OVERVIEW}

As shown in Table 9, the most important determinants of aerobic capacity at high altitude include acclimatization status, developmental status indicated by age at arrival to high altitude, ethnicity as measured by skin reflectance, activity level, and amount of body fat. These findings together suggest that attainment of aerobic capacity at high altitude is related to developmental acclimatization and genetic factors, but its expression is strongly mediated by environmental factors, such as occupational activity level and amount of body fat. As summarized in Figure 3, about 20 to $25 \%$ of the variability in maximum oxygen consumption expressed as $\mathrm{ml} / \mathrm{min} / \mathrm{kg}$ of lean body mass is related to 
TABLE 9. The most important determinants of varibility in maximal oxygen consumption (ml/min/kg of lean body mass) at high altitude

\begin{tabular}{|c|c|c|c|c|}
\hline \multirow[b]{2}{*}{ Variable } & \multicolumn{2}{|c|}{ Males } & \multicolumn{2}{|c|}{ Females } \\
\hline & Coefficient & Probability & Coefficient & Probability \\
\hline $\mathbf{R}$ & 0.76 & $P<0.01$ & 0.72 & $P<0.01$ \\
\hline Intercept & 72.43 & & 68.56 & \\
\hline Acclimatization status ${ }^{1}$ & 0.99 & $P<0.01$ & 0.02 & $P<0.01$ \\
\hline Age at arrival to high altitude & -0.20 & $P<0.01$ & -0.23 & $P<0.01$ \\
\hline Skin reflectance $(\log 10)$ & -28.11 & $P<0.01$ & -30.15 & $P<0.05$ \\
\hline Activity level & 7.35 & $P<0.01$ & 6.69 & $P<0.01$ \\
\hline Sum of skinfolds (mm) & 0.06 & $P<0.05$ & 0.09 & $P<0.01$ \\
\hline
\end{tabular}

${ }^{1}$ Acclimatization status (i.e., 1 = born; 2 = acclimatized to high altitude since birth or during growth; $3=$ acclimatized to high altitude during adulthood). Not in equation: age, height, weight, surface area, chest dimensions, residence at high altitude, smoking, chewing coca leaves.

\section{COMPONENTS OF VARIABLITY IN VO2 MAX AT HIGH ALTTUUDE}

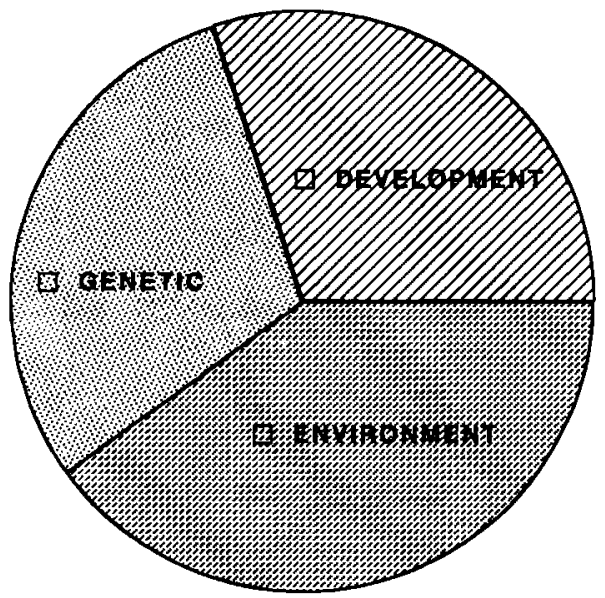

Fig. 3. Estimates of the components of variability in aerobic capacity at high altitude.

differential hypobaric exposure during development and about 20 to $30 \%$ is related to genetic factors. The rest of the variability in aerobic capacity is explained by environmental factors associated with variability in body composition and occupational activity level.

\section{ACKNOWLEDGMENTS}

This study was supported in part by NSF grant BNS9107236.

This study could not have been conducted without the enthusiastic cooperation of the volunteer subjects. We wish to thank the following laboratory assistants: Esperenza Caceres, Anna Maria Alarcon, and Cristina Gonzales from the Instituto Boliviano de
Biología de Altura. We also thank Deborah Schechter for her editorial and overall assistance.

\section{LITERATURE CITED}

Baker PT (1976) Work performance of highland natives. In PT Baker and MA Little (eds.): Man in the Andes: A Multidisciplinary Study of High-Altitude Quechua Natives. Stroudsburg, PA: Dowden, Hutchinson \& Ross, Inc.

Buskirk ER (1976) Work performance of newcomers to the Peruvian highlands. In PT Baker and MA Little (eds.): Man in the Andes: A Multidisciplinary Study of High-Altitude Quechua Natives. Stroudsburg, PA: Dowden, Hutchinson \& Ross, Inc.

Byard PJ (1981) Quantitative genetics of human skin color. Yearbook Phys. Anthropol. 24:123-137.

Conway DL, and Baker PT (1972) Skin reflectance of Quechua Indians: the effects of genetic admixture, sex, and age. Am. J. Phys. Anthropol. 36:267-282.

Coudert J (1993) Développement des voies métaboliques aérobie et anaérobie chez l'enfant Bolivien: Interactions entre l'altitude et l'etat nutritionnel. In F LeónVelarde and A Arregui (eds.): Hipoxia: Investigaciones Basicas $\mathrm{Y}$ Clinicas. Lima, Peru: Instituto Francés de Estudios Andinos, pp. 181-201.

Elsner RW, Bolstad A, and Forno C (1964) Maximum oxygen consumption of Peruvian Indians native to high altitude. In WH Weihe (ed.): The Physiological Effects of High Altitude. Oxford: Pergamon Press Ltd.

Fellman N, Bedu M, Spielvogel H, Falgairette G, Van Praagh E, and Coudert J (1986) Oxygen debt in submaximal and supramaximal exercise in children at high and low altitude. J. Appl. Physiol. 60:209-215.

Frisancho AR (1975) Functional adaptation to high altitude hypoxia. Science 187:313-319.

Frisancho AR, Martinez C, Velásquez T, Sanchez J, and Montoye $H$ (1973) Influence of developmental adaptation on aerobic capacity at high altitude. J. Appl. Physiol. 34:176-180.

Frisancho AR, Wainwright R, and Way A (1981) Heritability and components of phenotypic expression in skin reflectance of Mestizos from the Peruvian Lowlands. Am. J. Phys. Anthropol. 55:203-208.

Greksa LP (1992) Surnames as indicators of European admixture in Andean Indians. Int. J. Anthropol. 7: 41-49. 
Greksa LP, and Haas JD (1982) Physical growth and maximal work capacity in preadolescent boys at high altitude. Hum. Biol. 54:677-695.

Greksa LP, Haas JD, Leatherman TL, Spielvogel $H$, Paz-Zamora M, Paredes-Fernandez L, and MorenoBlack G (1981) Maximal aerobic power in trained youths at high altitude. Ann. Hum. Biol. 9:201-209.

Greksa LP, Haas JD, Leatherman TL, Thomas RB, and H. Spielvogel (1984) Work performance of high-altitude Aymara males. Ann. Hum. Biol. 3:227-233.

Greksa LP, Spielvogel H, and Paredes-Fernandez L (1985) Maximal exercise capacity in adolescent European and Amerindian high-altitude natives. Am. J. Phys. Anthropol. 67:209-216.

Grover RF, Reeves JT, Grover EB, and Leathers JS (1967) Muscular exercise in young men native to 3,100 m altitude. J. Appl. Physiol., 22:555-564.

Harrison GA (1961) Pigmentation. In GA Harrison (ed.): Genetical Variation in Human Populations. Oxford: Pergamon Press, pp. 99-115.

Klissouras V, Pirnay F, and Petit JM (1973) Adaptation to maximal effort: Genetics and age. J. Appl. Physiol. 35:288-293.

Kollias J, Buskirk ER, Akers RF, Prokop EK, Baker PT, and Piconreategui E (1968) Work capacity of longtime residents and newcomers to altitude. J. Appl. Physiol. 24:792-799.

Kushner RF, Schoeller DA, Fjeld CR, and Danford L (1992) Is the impedance index $\left(\mathrm{ht}^{2} / \mathrm{R}\right)$ significant in predicting total body water? Am. J. Clin. Nutr. 56: 835-839.
Lahiri S, Milledge JS, Chattopadhyay HP, Bhattacharyya AK, and Sinha AK (1967) Respiration and heart rate of Sherpa highlanders during exercise. $J$. Appl. Physiol. 23:545-554.

Mazess RB (1969) Exercise performance of Indian and white high altitude residents. Hum. Biol. 41:494-518.

Post PW, and Rao DC (1977) Genetic and environmental determinants of skin color. Am. J. Phys. Anthropol. 47:399-402.

Spielvogel H, Aparicio O, and Paz Zamora M (1988) Evaluaciòn de la capacidad funcional en fumadores en la altura. Communicaciòn ràpida del I.B.B.A. 1: 18-20.

Sun SF, Droma TS, Zhuang JG, Tao $\mathrm{XX}$, Huang SY, McCullough RG, McCullough RE, Reeves CS, Reeves JT, and Moore LG (1990) Greater maximal $\mathrm{O}_{2}$ uptakes and vital capacities in Tibetan than Han residents of Lhasa. Respir. Physiol. 79:151-162.

Velásquez $\mathrm{T}$ (1966) Acquired acclimatization to sea level. In Life at high altitudes. Pub. 140. Washington, DC: Pan American Health Organization.

Velásquez T (1970) Aspects of physical activity in high altitude natives. Am. J. Phys. Anthropol. 32:251-258.

Velásquez T, and Reynafarje B (1966) Metabolic and physiological aspects of exercise at high altitude. Part 2. Response of natives to different levels of workload breathing air and various oxygen mixtures. Fed. Proc. 25:1400-1402.

Way AB (1976) Exercise capacity of high altitude Peruvian Quechua Indians migrant to low altitude. Hum. Biol. 48:175-191. 